\title{
The 'Original Sin' in History: An Investigation into the Role of Iconoclasm as the Engine of Western History
}

\author{
Prashant Kumar Singh \\ University of Hyderabad
}

\begin{abstract}
History has been interpreted in many ways in the past and will continue to be done so in the future. From logical play of spirits to a series of negations; from evolutionary stages to revolutionary struggles; from court histories to subaltern histories; we have seen it all. In spite of so many variations, they all revel in some kind of eschatological aims, with or without god. The aim of this paper is to look onwards from a specific epoch in history, which Karl Jaspers (1953) has referred to as the Axial Age. The Axial Age has been considered as a period of ideological and spiritual revolutions, signifying a break from the past historical trajectory. The paper argues that apart from ideological convulsions, this period also introduced a violent strain of iconoclasm that has constantly made its appearance in all historical epochs. The paper has tried to argue that these iconoclastic acts have forced the Western history or more specifically, the Abrahamic monotheistic world into a compulsive-repetitive flow of history.
\end{abstract}

Keywords: Original sin, iconoclasm, history, Theocides, nihilism.

One day, a day lost in ancient memory, but from which all our history has subsequently developed, the more intelligent of our desert dwelling ancestors became tired of having to carry heavy statues of the myriad gods around in the desert - the golden calves, the hollow plaster goats.

They decided to drop these pieces of marble and metal

Social Evolution \& History, Vol. 20 No. 2, September 2021 133-156

(C) 2021 'Uchitel' Publishing House

DOI: $10.30884 / \mathrm{seh} / 2021.02 .06$ 
which obliged them to pursue the localized life styles of sedentary population. They decided to travel light...Their bodies were suddenly freed of shackles; they had free hands, unladen shoulders and all at once it seemed to them as if they were flying, across the plain, beneath the vast empty spaces of sky - which their newly raised heads could now see for the first time - and they say, because all they had left was words and music... (Serres 1995a: 35)

When the Inquisitor has finished speaking, he waits for some time for the prisoner's reply. His silence distresses him. He sees that the prisoner has been listening intently to him all the time, looking gently into his face and evidently not wishing to say anything in reply. The old man would like him to say something, however bitter and terrible. But he suddenly approaches the old man and kisses him gently on his bloodless, aged lips. That is his entire answer. The old man gives a start. There is an imperceptible movement at the corners of his mouth; he goes to the door, opens it and says to him: 'Go, and come no more - don't come at all - never, never!' And he lets him out into 'the dark streets and lanes of the city.' The prisoner goes away (Dostoyevsky 2008).

Following Deleuze, we know that it is not an idea or an object but rather an assemblage that should be the unit of analysis. While analyzing history and historical events, we tend to emphasize too much on the strength of ideas to be the sole representative and mover of history. The single-minded focus on the power of ideas leads to the interpretation of history as continuous logical play of spirits and forces. Although ideas do play an important role, they are not alone in influencing the course of history. Shapin, while investigating the medieval history of Europe argued that Hobbes's Leviathan would have been powerless without Boyle's Air pump (Shapin and Schaffer 1985). This amalgamation of ideas, objects, events, inventions, heroic acts form an assemblage that together affects any particular epoch in history. The recent developments in systems and complexity theories and their application in historical analysis have shown that there is no single law of causality in history (Bondarenko 2007; Baskin and Bodarenko 2019). The spiritual and ideological revolutions of the Axial Age pre- 
cipitated because of wide ranging changes in the social milieu of that time and these revolutions borrowed and transformed the preceding world stories or myths (Baskin and Bondarenko 2014, 2019).

In that multivariate assemblage, ideas alone cannot achieve anything unless accompanied by other tangible factors. Keeping this in mind, the present paper argues that though the Axial Age resulted in spiritual transformations, yet we cannot ignore the hard historical fact of iconoclasm that these revolutions initiated. Friedrich Nietzsche, while a staunch critic of Christian moral order, also understood the importance of axial age spiritual revolutions in molding the history in the repetitive mode. According to him, the problem happened when the moral codes were raised to the level of Metaphysics, making them sacred and immutable in world religions. Nietzsche, in the introduction to his book Thus spoke Zarathustra explained why he chose Zarathustra to strike the edifice of religion, God and morality. It was Zarathustra, the first prophet who elevated morality to the metaphysician level and therefore it was his duty again to lower it from that high pedestal. Forces are dynamic and any system that attempts to domesticate it has to be dynamic with its techniques and procedures. Religions falter in this exercise because they have made these technical manuals into divine jurisprudence. In this aspect, more than Christianity, the heirs of axial revolutions, in the form of Judaism and Zoroastrianism, that molded the historical trajectory in by constructing big dams on the historical flow for the first time. While Zoroastrianism elevated morality to the level of divine, Judaism sanctioned iconoclasm as kind of religious activity, sanctified it in religious canons.

Taking a cue from this insight, the present paper argues that the search for continuity in history should not limit itself to joining the threads of ideas that have occupied important place in every epoch; the historical analysis should extend the ambit to look for acts and events that have continuously resurfaced in one form or the other. The main argument of the paper revolves around the thesis that the spiritual and ideological revolutions of the Axial Age brought about a very drastic and permanent change in our perception about things and their truth value by legitimizing the acts of iconoclasm. Starting from the Axial Age to our contemporary period, spanning over 2500 years, the trajectory of history has been continuously disrupted by numerous revolutions and counter revolutions and they all have manifested varying shades of iconoclasm. Though the religious and spiritual revolutions of the Axial Age (in the form of Buddhism, Jainism, Zoroastri- 
anism, Judaism, and Confucianism) enveloped the entire world, the rise of Judaism and its impact on the course of Western history till modernity has been widely acknowledged and documented (Baskin and Bondarenko 2014; Gillespie 2009). This paper therefore primarily focuses on the historical trajectory that Abrahamic religious revolutions and their acts of iconoclasm have initiated, starting from the work of redactor in the Babylonian captivity and the rise of Judaism around 2500 years ago. Is it not possible that all the mutations and transformations happening in ideas and ideologies overtime are possible because of a particular act continuously affecting the idea from within? The paper has tried to investigate the role of act of iconoclasm and its continuous resurfacing in different forms affecting the course of history and thereby giving history its compulsive-repetitive nature.

\section{THE FALL OF THE ANTIQUITY AND THE DEATH OF GOD: THE TALE OF TWO EVENTS}

The first quote talks about the abandonment of gods for the sake of one God, with the rise of monotheism, in antiquity, while the second talks about the banishment of God from the world, in the late nineteenth century. If the two quotes could be considered as two marking points in the landscapes of Western history, separated by almost two and half millennia, then it suggests that something has happened between them, something has flown between these two points and that these marking points give this historical flow, from gods to single God to no god, its trajectory.

If the 'allegory of cave' distinguished between knowledge and ignorance, then for our purpose we have to use something like the 'allegory of dams' on history. If we visualize these two marking points as two dams, then the history that unfolded could be understood as the flow of a river, flowing from axial age to modernity. The turbulent, chaotic and diverse set of flows are interrupted in the passage by a controller, by a big dam that puts a brake in the movement and channelizes it in a controlled way to a series of dams built on the course of a river. What the dams located downstream receive depends on what and how much the upstream dam releases. Each dam acts as a link in the chain of flows, dependent on its antecedent and subsequently deciding for the consequent. This allegory of dam enables us to visualize the two theological disruptions: the successive worldviews and the historical events in terms of channelized and interrupted flows, of carrying forward to the next level of the things received at the previous level. 
The transition from polytheism to monotheism ensured that only one type of truth remains valid and multiplicities that could hinder the emergence of that single truth must be weeded out. When we talk about flows in history, we mostly talk about the worldviews and ideas that are sole claimants to status of truth. The multiplicities do survive but they mostly remain as undercurrents or side currents to the mainstream and occasionally cause turbulence in the mainstream.

Keeping this in view, the two passages maybe thought of as narrating two historical events, the two acts that have decided to a large extent, between themselves, the course taken by the history. The first act, 'Death of gods' for the sake of God, symbolized by Jewish monotheism, which catapulted an entire civilization on a new trajectory was very much same as the construction of the first big controller, a dam on the natural course of the river and everything ensues thereafter. The second act, 'Death of God' at the peak of modernity, was akin to the construction of the second big dam separated by a stretch of almost 2500 years. The second dam was preceded by a whole lot of cascading dams linking it to the first dam and what appeared at the channel gates of the second one was the flow that had been dammed innumerous times. Between these two events, unfolded an entire history; a history documented to the last detail from every angle, social, economic, political, spiritual, technological; ordered into various stages of growth, savagery, feudalism, capitalism, communism; labeled into periods of dark ages, renaissance, reformation, revolution, modernity, and post-modernity. Yet it seems that when it comes to the question of why it happened the way it happened and not the other way, there are few answers.

Friedrich Nietzsche (1974a, 1974b), who formally announced the 'Death of god', the God who was lying on his death bed for a long time, knew that the created (God) won't survive the creator (Man). After all it was the God himself who was created by that first theocidal act. With that first act was born an all-powerful God usurping the powers hitherto distributed, and the second theocidal act killed a highly emaciated God that was usurped of all its powers (Nietzsche 1974). The story of whole history, the purpose of all revolutions has been the gradual usurpation of the territory and the powers granted in the beginning to that God. The cascading effect of check-dams, symbolized by all the revolutions and counter- revolutions that have taken place, has been the progressive emaciation of that God throughout history (Stengers 1984; Voegelin 1952). Nietzsche saw the affinity 
between the two events when he declared, while pronouncing the death of Christian God, that Nihilism itself was the product of Western history (Deleuze 1983; Nietzsche 1974), which started with the first theocidal act. Historically, the first theocidal act could be understood as the original sin of the Western humanity, out of which they have never recovered and the later generations, through numerous revolutions and counter-revolutions have successively paid their obeisance to this act by constantly repeating it, in thought and action. In theologies and cosmologies, this act has been allotted a very strategic role; a role when duly performed would reveal the unrevealed, manifest the hidden (Latour 2010, 2013). The first act, the original sin revealed omniscient, omnipotent, omnipresent God in all its glory, hidden till now in the crowded pantheon, whose message was interrupted by the noise of the cacophonous gods. What it also supposedly recovered were the eternal qualities of Truth, Unity, Beauty which could now belong exclusively to the rightful candidate, to the most deserved one, the Absolute in all the senses of the term, to the God. The living worldly gods with their corruptions and human like fantasies were not suitable candidates for these sublime qualities.

More importantly, what this act furnished, may be for the first time, was the universalization of an ideal which hitherto belonged to philosophical circles and was the domain of a very limited number of people (Ridley 2015, Sloterdijk 2013). Worldly gods for worldly affairs were replaced by impersonal, other worldly God for worldly affairs. With the advent of Judaic monotheism and later with the spread of Christianity, this became a common possibility for large number of people (Sloterdijk 2013). The unqualified universalization of an ideal in the form of God marks the initial or first phases of history, after the first theocidal act, on a trajectory that is documented as Western history. This laid the foundation for the first world order which was entirely based on an ideal, a ruling idea. It was strikingly different from previous orders which were mostly about kings and territories, and conquests. These older orders rarely interfered with the worldviews of the conquered people, were hardly motivated by any ideal other than the personal motives of the ambitious kings and tyrants. What gave the new world order its peculiarity and its driving force was this shift from the personal motives to an impersonal ideal with its own dreams of universalization. Vidiadhar Surajprasad Naipaul (1981), while discussing about the Arab conquest of Sind in his 
travelogue, also mentioned this shift in the nature of conquest, from personal motives to an impersonal ideal.

The shift to monotheism with the theocidal acts furnished at one stroke three things; firstly, the expulsion of worldly gods for worldly affairs; secondly, retrieval of an impersonal God in the singular; and thirdly, which was also the political one, the unqualified universalization of an ideal with a quest for becoming world power. The construction of this first big dam diverted the different flows along this trajectory with three identifiable features mentioned above. Everything that has flown in this direction, everything that has happened of significance has carried these ineluctable marks on its design and operations.

If we generalize these three outcomes in philosophical terms so as to formulate a general principle, a common philosophy of Western history, it would be something like that; the search for truth started with the unraveling of the multiplicity, then discovery of an immutable spirit of ideal and finally prioritizing this ideal over everything else. Uncover, Discover and Inhere. Judaism, Catholicism, Protestantism, Renaissance, Scientism, all are heir of the kingdom founded on that Original sin, the first theocidal act.

\section{ICONOCLASM AND THE PURGING OF NON-HUMANS FROM HISTORY}

We have marked the historical beginning with the theocidal act, the killing of gods, but what exactly was the way in which the act was committed. Were the gods killed literally in flesh and blood? And if not, then how was it done? How the grand act accomplished itself? The preparatory ground work leading to these acts has been recorded very piously in all the Abrahamic theologies. The tales of a son accusing his father and his people of naiveté and destroying the idol-shop of his father are at the origins of every theology (Assmann 2008). Though the creation myths appear to be trivial, just an accusation, yet it produced ripples that traveled far and wide.

Actual breaking of idols are always preceded or accompanied by asking set of questions that were not asked before (Latour 1999). Was it really a revelation to state the obvious that the idols were made of stone and they could not speak, think or move? The people who were making idols with their own hands must have known as a matter of fact that they were making it with stones and these stone idols could not speak, think or move (Latour 2010). At face value, the only intended purpose to state the obvious fact seems to publicly embarrass 
the icon holders by showing the incapacity and inability of idols to move things. And it did so by directing questions to idols that hitherto were not asked or considered worthy enough to ask.

Bruno Latour, while discussing the history and nature of iconoclasm in Abrahamic religions, says that the iconoclasts start with a wrong premise, the idea of Belief (Latour 2010). The iconoclasts start by accusing the people of naiveté and believing in the power of false images and stone idols. And he does that by instituting a public trial of idols and showcasing their defenselessness in the face of incessant queries. Was the father and his people were really embarrassed by this public trial? Were they thankful to this prodigious son who dispelled their ignorance and naiveté? What the father said, 'Why do you mock me? Do these idols know anything (to speak and move),' shows that the allegations of belief and ignorance were unfounded. The belief was there but, as Latour argues, it was the son and not the father who possessed it. The son was the true believer who believed that people naively believe in things and idols (Latour 2010). The father knew, it seems from his answer, that the idols were not supposed to reply to the questions asked by the son, not because they were incapable of answering it, but because they were the wrong questions. The idols were not designed to answer those questions (Latour 1999, 2010) and they did the right thing by not answering those questions. The questioner, in a hurry to scandalize the idols and idol owners did not frame the right kind of questions.

To get a glimpse of what those hasty questions were, we just have to go through the repetition of that Abrahamic trial, in an imaginary dialogue between a theist and an idolater, composed by Raja Ram Mohan Roy in a book in the early nineteenth century (Hay 1963) where the same sort of accusations and justifications are at play which were present at the beginning. Although it is interesting to note that the same answers, this time given by the idolater in his defense are again making their way into the scheme of things, albeit through a different route.

The Ideas of mediation, translation, inheritance, transference, agency, instruments, and articulations are again making our vocabulary rich to enable us to talk about our world in a dynamic way. In the eternal Abrahamic trial, it is the time itself that has now become the attorney of idols.

We never experience the world directly, for we need properly coded and historically recorded ideas and behaviors to arrive at an 
experiential relation with the world. We never experience even the God directly; this was the simple message of all the icons and idols of this world. The idols, the images, the gods and their dwelling places were the key points in the landscapes which not only marked them but also connected them in multiple ways (Campbell 2004; Simondon 1958). They facilitated as well as guided the movement, established the relations, mediated the transformation from one form to another. They were neither false projections nor inert matter but active totemic operators designed to navigate the different worlds easily and smoothly. To use a current denotation given by Michel Serres, they were 'Interchangers', meant for extending and switching networks,

Every interchanger permits one to change between spaces, levels and orders which may be heterogeneous among themselves and to construct a oneness of the universe while at the same time maintaining local differences (Serres 1995a: 170).

In the absence of interchangers, the task of connecting to a network, as well as of connecting to the world, and of universalizing would lack the necessary operational resources. The cosmologies which came after this original sin had very little to do with the world and therefore the amount of interchangers required for their realization was consequently very small. Doing away with concrete idols and key points, distributed throughout the landscapes, as false entities, the new cosmologies replaced them with a set of interchangers that were very few and highly centralized in nature. As far as the world was concerned, they had very few things to say about it other than that it had to pass through or connect to these interchangers in order to have a qualified existence.

Iconoclasm played a pivotal part in the formation and consolidation of the cosmologies which came into being after that original sin. Iconoclasm is a powerful mechanism that makes its presence felt repeatedly, returning with a vengeance to clear the alleged mess that grows over time. From the beginning of the history, it has returned again and again to repeat the task initiated at the origin of this historical trajectory. If something like this is built into the founding principles of any competing theory, ideology or theology, as an aid in search for truth, it is unlikely that it would stop after its first successful execution.

There is an inheritance in iconoclasm also; even iconoclasts have lineages and progenies. Iconoclasts act in the present but at the same time create something for the future generations of iconoclasts to de- 
stroy. By destroying in the present, it uncovers something which acts as a raw material for next round for destruction. If we start making an inventory and chronology of things destroyed and replaced over two millenniums, we would arrive at a truly materialist conception of history. A good number of object centric histories have been written, especially by those who engage in social studies of science but they are mostly of the secular kind; that is they trace the histories of scientific objects in their social contexts (Bijker 1995; Daston 1998; Simondon 1958). They have shown how scientific objects and inventions have defined and redefined social relations (Bijker 1995; Diamond 1997). If a historiography showing gradual devaluation of the things and their status in the world is being carried out, it could reveal the continuous presence or workings of the iconoclastic principle.

The first wave of iconoclasm destroyed the idols of different gods and replaced them with icons and images of the son of God, mostly associated with the rise of Judaism and Christianity (Assmann 2008). The second wave of iconoclasm represented by reformist movements like Protestantism destroyed these icons and images and replaced them with only words and messages (Voegelin 1952). The third wave of iconoclasm, through scientific revolutions did away with these words inscribed in the book and replaced it with divine will and design (Stengers 1984). The fourth wave of iconoclasm removed the divine will and design of the God and ultimately put the God to rest in peace an aptly summed up as nihilism (Nietzsche 1974b). This last wave resulted in the second theocidal act that finally removed the God from the scheme of things and from this point on 'Man' came to occupy his throne.

If the first act created an abstract absolute God in place of concrete and differentiated gods, this second act created an abstract Man in place of an abstract God. This second theocidal act was therefore the second big check dam erected on the flow of history from where it was reoriented into another direction. This check dam again, while receiving its flows from its antecedents, intercepted, controlled, checked and diverted the different streams accumulated over period of time into one single stream that would now qualify as the flow of history.

For our purpose, we have followed a rough classification of Western civilization into three stages. The pre-history ends and the history begins with the first theocidal act. Then came the God stage, covering the period between the two theocidal acts in which God is thought upon with varying power and jurisdiction. Finally, there is Man stage 
starting more or less after the second theocidal act, whereupon theologies are replaced with Man centric ideologies. In the God-phase of history, the attributes of God were drastically changed with depreciating capacities and jurisdictions. The process of immanentization ${ }^{*}$ and the acts of iconoclasm resulted in the transformation of God from being an absolute monarch to an emaciated divine-will hidden in the design.

Immanentization and iconoclasm as operating principles were not abandoned with the termination of God, in whose genesis, they acted as facilitators but are carried forward to the next stage, the Man-stage. Upon entering the Man-stage in history, the world was completely emptied of non-humans and material beings. Just as knowledge extends by adding mediators and successive connecting links (James 1978b; Latour 2013), so does iconoclasm by dismantling successive mediators and connecting links. Dismantling of mediators by iconoclasm means the denial of their truth value and their autonomous existence. Each wave of iconoclasm, in the renewed enthusiasm for search of truth, peels off few layers from the composite body and chance upon a new body of truth which is more fragile in nature. Destruction of golden calves, Greek temples, idols of gods and goddesses, destruction of statutes and images of Jesus Christ, Virgin Mary, defacement of catholic churches, rejection of the book and the message and the death of God form the sum total of acts propelling the Western history in its compulsive-repetitive march.

Looking at the history from object's point of view, it seems that for the proponents of truth, truth and visibility are two irreconcilabilities. If something is visible, has a definite form, well grounded, then it does not qualify for being true. The visibility and definite form of something gives access to anybody and everybody, to manipulate, mold, employ and possess, thereby making it very malleable. Visibility gives in to the multiplicity of the world; it lacks the rigidity and the absolute eternal nature, deemed as essential qualifications of truth. It does not have much use of the 'allegory of cave' and the 'enlightened souls' and that is why it attracts the wrath of almost all truth seekers and prophets who believe in the absolute nature of truth. The desire to destroy the forms springs from that idea of truth which is invisible as only invisibility can protect its pristine sublimity from the dangers of mutations and degradation. In this respect, iconoclasm has to be an everyday exercise; the iconoclasts should always be ready with their 
hammers to strike at the first signs of visibility and formation (Latour 1999, 2010; Serres 2015).

Seeing can make one witness the transformation taking place, can induce vulnerability towards the enchanting forms, can make one possessed by them but believing has no such pitfalls. It can maintain its eternal nature in spite of anything happening around its vicinity and in the world. Believing protects one from being enamored by the world. Believer never loses sight of that eternal truth, and always has its hammer ready to give deathly blows to anything capable of disturbing its tranquility. Believing cannot succeed in a world which has multiple reference points and sources of truth, where non-humans have definite and concrete existences and compete for priorities. The prerequisite for believing is an empty landscape and to empty the landscapes, iconoclasts are commissioned with their hammers. Believing creates an empty landscape and the more one firmly believes, the more empty the landscapes become, and the more violent the urge to destroy the forms become.

The successive flattening of the landscapes and subsequent increase in speed and mobility led to what has been called as the era of capitalism, the era of unbridled expansion and production, an era of minimum roadblocks and resistances. We can now understand the genesis of capitalism in these acts of believing. In the sacred tradition of believing, the foundations for capitalist expansions were laid (Weber 2003). It should not be confused that everywhere the act of believing would lead to the type of expansion and proliferation associated with capitalism. Believing, which comes inbuilt with iconoclasm, opens up at least two possibilities, one moves outward in the direction of proliferation and the other inward in the direction of purification. One proliferates the landscapes with objects, non-existing existents, present but not true; the other expurgates and purifies landscapes of nonexistent existents.

In the religious domain, it tends inward, to the source and indulges in destruction of everything that has been created having sacred value. In the secular domains, it moves forward in a fatalistic way, abandoning and dumping the things it has created to create more and more new things, only to be abandoned like the old ones, thereby choking the landscape. If one leaves you lost in the immense desert, the other leaves you choked in a lethal jam. In one landscape, you can 
go anywhere you want but do not know where to go, in the other you know where to go but cannot go anywhere. This shows that the question of agency is also a question of how we design our landscape so as to avoid both the situations. The present ecological crisis is the outcome of the second type of landscape formation, the secular one, of our choking the life sustaining capacities of earth. It does not mean that the architects of former landscape, the religious one, the landscape of desert are out of work in modern age. Global terrorism and the spectacular phenomenon of suicide bombings are the products of the religious landscape creation. Two entirely different phenomena, ecological crisis and terrorism, share the same founding principles, the inability to make peace with forms. One does not care about forms, other cannot tolerate forms.

\section{INTO THE MAN-AGE AND MUTATIONS OF ICONOCLASM}

While studying about history, few great minds of the nineteenth century had clearly sensed the driving force powering the motor of history. Most important among them were the Marxian theses that all history hitherto is the history of class struggle or the Hegelian idea that it unfolds in the spirit of negation and negation of negation, and finally the Nietzschean statement about nihilism as the logical product of the Western history. Out of these, the last one about nihilism was more specific because it saw in the origins of history, the seeds of nihilism. The first two were also in the right with only a slight defect, they were generalized too hastily. 'All history' in these statements was over generalizations. By limiting their scope to only Western history, we not only understand it more precisely but could also give voices to other 'ways of history'.

Mere dialogues and questioning would not suffice as acts of iconoclasm. One needs a hammer and an enthusiastic individual wielding that hammer. And everything follows after that. History as a site of struggle and conflict between theses and antitheses boils down to these practical acts. One group advancing to destroy and replace other groups idols, images, totems, Books and the other group trying to protect their symbols or two groups fighting it out for the supremacy of their symbols, preparing the ground for next generation of iconoclasts with new images or nothing at all. That is also the logic of the Hegelian thesis of negation of negation. One comes into the existence by 
negating the existence of its predecessor which in turn is negated by its successor. It is through a series of negations, that we come upon the Age of Man in its pristine glory, a man occupying the position of God.

The transition to this age was the result of the changing nature of Science, following certain discoveries in the nineteenth century, which reframed its ontological assumptions. The pragmatic philosopher William James highlighted this shift while talking about new challenges presented to the idealist conception of Truth by these new sciences,

Up to 1850 , almost everyone believed that sciences expressed truths that were exact copies of a definite code of non-human realities. But the enormously rapid multiplication of theories in these latter days has well-nigh upset the notion of any one of them being a more literally objective kind of thing than another. There are so many geometries, so many logics, so many physical and chemical hypotheses, so many classifications, each one of them good for so much and yet not good for everything that the notion that even the truest formulae may be a human device and not a literal transcript has dawned upon us (James 1978b: 206).

In the idealist framework of Science, the conception of truth was that of a grand design and divine will inscribed in the laws of nature. The God was just a loose presence in the transcendental realm with no active powers in the world (Stengers 1984). The world in its own was either realized or advancing towards the realization of that will. This type of world had its corresponding set of ethics in theological doctrines and both science and theology fed into each other ideas about truth and purpose. The proliferation of the scientific activity, as described by William James jeopardized the old notion of design, contained in few laws (James 1978b). The increasing number of laws and scientific disciplines made it very difficult to arrange them in coherent set of design speaking the same language and ultimately the suspicion that whether there has been any design or designer at all. Is it possible that before Nietzsche proclaimed the death of God, the God was probably dead long ago? Can we say that it was not a case of violent execution but of extreme negligence, leaving one to die on its own?

Just as in the first act, before the hammer of iconoclasts striking down the idols, there was a public trial to embarrass and humiliate them; so was in this case. There was a prolonged public trial happening just at the time when he was abandoned for all practical purposes 
and which has gone down in history as a period of nihilism. In principle, nihilism was an advanced stage of iconoclasm. It was advanced in the sense that it did not have to deal with concrete things but with ideas which were part of immanence/transcendence dichotomy. This was a period of churning, leap, shifts and jumps wherein new plugins were searched to fit in to the new scheme of things without God. The code of ethics imported from theology was proving incompatible with the new system requirements, which instead of facilitating the expansion and proliferation of new scientific activity, was cramping it with its useless requirements of morality.

The readers of pre-revolutionary Russian literature are familiar with the anxieties and churnings of that period, when old orders based on morality and ethics were challenged by a new scientific milieu, still in a nascent state but powerful enough to cause embarrassment. We just have to go through the novels of Fyodor Dostoyevsky, especially 'The Brothers Karamazov', 'Crime and Punishment' and 'The Possessed' (1970) or Turgenev's 'Fathers and Sons' to get a glimpse of that conflict. The protagonists in these novels inhabited something like no man's land; they occupied a place in the society which could be described as anything but comforting. The heroes of these novels; Ivan, Raskolnikov, Stavrogin or Bazarov were not heroes in the strictest sense of the term. They were tormented personalities, but no one to blame for their predicament except themselves. They were enthusiasts of the new sciences and its revelations but did not know what to do with these truths in the existing world, were unable to codify them as sources of meaningful action.

In a society where an individual's life, from explicitly social to the highly intimate sphere, was elaborated to the last detail in codes sanctioned by divinity, any threat to the idea of divinity itself would be shattering. If an idea loses persistence, what happens to the life which is totally dependent on that idea for its own existence? Without the active presence of God, the morality derived from that God becomes a dead weight on the shoulders of an individual and society as a whole, crushing its vitality. The nihilists were the first ones to sense the crushing effect of that dead mass of morality and assisted by the energies of new truths, threw them at once to live without their succor. But they had a whole society to fight, a society in which old habits die hard and people carry on with their lives without much concern about new truths and old paradoxes. 
Driven by despair and desperation, these individuals threw themselves, in a fit of rage and vengeance against morality and society, doing everything that was proscribed and sinful. Since nothing concrete and objective, in the form of objects, was left to destroy, they chose the only thing left to destroy, morality. Motivated and armed by the newly found truths and in defiance of vacuous morality, they committed what was considered as the gravest sin, homicide (Dostoyevsky 1967). Some killed others, some committed suicide. In death as in life, they remained truthful to their truths. A truth, whose time of recognition had come but which needed few martyrs before its claim for the throne would be recognized. Nihilism was the transient period from Theism to Humanism. It was the liminal phase between the dying world of theism and an unborn world of humanism, with man as the center of universe. The theory of Man and its associated milieu has been termed as Humanism.

While nihilism was demolishing the artifice of religious morality, there were simultaneous attempts going on to replace this old and tattered worldview with a new and coherent worldview. A homocentric worldview along with the new set of commands and codes to reorient an individual's life in particular and society in general. These worldviews belonged to the realms which are known as ideologies, and which accompany the nihilistic phase in history. One was doing away with the old one, and the other was creating a new one. Humanism, Marxism, Anarchism, and Socialism are different ideologies that tried to formulate a coherent set of principles to qualify as convincing and sufficient teleology. Genesis and a sense of purpose were rearticulated in secular and historical terms, borrowing heavily from the findings of science about life and evolution. The individual was reinserted into the new scheme of things with a different role, place and destiny in history and in the world. Scholars have shown the Judeo-Christian legacies of the nineteenth-century ideologies (Eliade 1975; Gillespie 2009). Some have referred modernity as symptomatic of a new wave of the Axial Age (Baskin and Bondarenko 2019). Instead of waiting for the kingdom of god, the individual was assigned the task of creating the kingdom of god in this world, aided by the scientific facts and driven by the force of history and self-reflexive consciousness. 


\section{CONFIGURATION OF WORLDVIEWS IN A POST-THEOCRATIC WORLD}

In nineteenth-century Germany, Wilhelm von Humboldt, a natural scientist and an educationist, came up with an education model which proposed the union of teaching and research in search of truth. It envisaged a unity of life based on the scientific principles and truths. The result was the establishment of Berlin University in 1810 to advance knowledge through original and critical investigations and its dissemination through teaching (De Ridder-Symoens [ed.] 1992) As Lyotard has rightly assessed that the idea of Humboldtian education was based on the conviction that truth would take care of everything else, it alone could provide the desired unity in life (Lyotard 1984). A life based on the principles of scientific truth and scientific attitude would provide a solid foundation for the society in which moral, aesthetic and all other aspects could be woven into one whole. It was sufficient to direct all our attention and receptivity to the truths generated by the scientific practice and everything else would fall in place; as only those practices sanctioned by the science are capable of giving a complete and satisfying existence. In one sense it was a departure from previous worldviews since it talked about truth in the plural as compared to the absolute truth of earlier versions. But overall it inherited the legacy of its predecessors in claiming the absolute status for its version. Only one realm, one sphere had the legitimacy and the validity to pronounce truths and everything else has to be designed taking this into account.

Apart from the proliferation in number of natural sciences disciplines, dedicated to the objective study of nature, there emerged a number of disciplines for the scientific study of society and individual using the methods and tools of natural sciences. Disciplines like sociology, anthropology, history were concerned with the objective explanation of society so as to establish a certain principle or law akin to natural laws working behind the foundations of society. In fact, a considerable portion of what we understand as society has been described by these disciplines using the parameters of established science and that is why they were referred as scientific study of society (Giddens 1971). Marxism with its classifications of base and superstructure posited an operating principle that guides societal functions and on proper analysis could be shown behind every sphere of life. 
The birth and the rise to the level of universalism, of previous truths inevitably led to their breaking up and fall. The universalism of scientific truth after accelerating the movement and innovation to magnificent levels began to show its shortcomings. The physical destruction of the planet as well as the poverty of its worldview in producing a desired unity of moral, spiritual and aesthetic realms resulted in a new wave of disenchantment. But this time the breaking up of scientific grand narrative and the loss of hope in the project of modernity was not followed by an enthusiastic embracing of a new universalism (Lyotard 1984). A kind of exhaustion and melancholia had crept in at the continuous failings of one truth after another (Bauman 1997). Countless imperial wars, violent ideological battles, bloody revolutions and world wars were waged for realizing the human destiny of attaining the unity of life. Cioran poignantly summed up all this by lamenting history as a procession of false absolutes (Cioran 1975).

Peter Sloterdijk in his remarkable way has approached the history of the West through the repetitive manifestation of cynical impulses. He has used the term 'kynicism' to differentiate it with cynicism (Sloterdijk 2001). Kynicism has an element of playfulness, an affirmation of life and a self-embodiment of impulses. It mostly has a resistive nature and comes from below against the coldness and formality of the rule. Cynicism, on the other hand, is what becomes of kynicism when it occupies the throne. It results in self-splitting and selfrepression (Sloterdijk 2001). Kynical impulses could be understood as something similar to the enthusiastic and innocent reception of truths in their nascent state. The kynical impulses have given in history the much needed respite from overarching truth requirements which became suffocating after some time.

Through all the changes in world history - decline of the western Roman empire, the Christianization of the Occident, the rise of feudalism, the age of chivalry, the Reformation, the Renaissance, absolutism, the rise of the bourgeoisie - the kynical impulse has continued in the most varied refraction and disguises (Sloterdijk 2001: 175).

Manifestation of kynical impulses always showed the possibility of recovery of lost or marginalized values, values which always mixed wisdom with childlike playfulness and cheekiness against the gloomy nature of high morality, as portrayed by Diogenes in ancient Greece (Sloterdijk 2001). The phase of romanticism was also an exercise in 
the recovery of life affirming values denied by the moral world of monotheism. What characterized the late modern world, which has seen its trust broken and hopes shattered by the exaggerated promises of scientific rationality, according to Sloterdijk (2001), is the permeation of cynicism to the general level, of it becoming a common possibility. The transition from kynicism to cynicism at mass level is what has plagued the modern world. It is no longer limited to the world of rulers or coming from above but at once has removed the distinctions.

Unlike kynicism, cynicism cannot recover any lost or marginalized values since it does not recognize the existence of any such values other than values it has inherited. Cynicism is never a rebellion against inherited truth and values; it never questions their validity in theory but only realizes its impossibility in practice, to use a Sloterdijkian phrase, 'bogged down by reality' (Sloterdijk 2001). Before moving on to cynicism as an outcome of the impossibility of applying a theory to practice, we have to discuss the Marxian attempts to apply theory to practice and the results that ensued from that attempts.

Marxism was an inverted form of Hegel's idealism. As it is famously said that Marx simply brought a theory, which was standing on its head, back on its feet. The dialectics in Marxism happened between concrete things and real forces, moving positively on their way towards the realization of the ideal of classless society and new man. But with the visible incapacity of the science as a luminous force in the impending unity, the Marxian dialectics based on the principles of scientific rationality came under suspicion. The events of Russian revolution and the reign of violence that ensued thereafter forced many to challenge the vision and the values advocated by it.

This led to another inversion within the traditions of Marxism, this time Theodore Adorno and his critical theory school. To see the fate of dialectics as an instrument of power and imperialism in the hands of rulers and victors, it reacted by totally inverting the ideas considered to be essential for the progress.

The conviction that the real is written in the hand of suffering, coldness and hardness determines the way critical theory approaches the world. Although it scarcely believed in a change for the better, it did not give in to the temptations to desensitize itself or to get used to the given order of things. To remain sensitive was, as it were, a utopian stance - to keep the senses sharpened for a happiness that will not come, a stance that 
nevertheless, by being prepared for happiness, protects us from the worst kind of brutalization (Sloterdijk 2001: xxxiv).

Furthermore he states that for critical theory, to oppose everything that reeks of power and confidence became the modus operandi of existence:

Politically and in its nerve endings, this aesthetic, this sensitive theory, is based on a reproachful attitude, composed of suffering, contempt and rage against everything that has power. It makes itself into a mirror of the evil in the world, of bourgeois coldness, of the principle of domination, of dirty business and its profit motive. It is the masculine world that it categorically rejects. It is inspired by an archaic NO to the world (Sloterdijk 2001: xxxiv).

Against the positive dialectics of classical Marxism, Adorno proposed the idea of negative dialectics, which simply distrusted the ideas advocated by the victors and rulers; it shifted its attention from the ideology of emancipation of society and individual to a higher lever to that of the liberation of individual from the society through heightened sensitivity. Negative dialectics, in the words of Sloterdijk,

Openly gives up the attempt to compulsorily be in the right and to celebrate the force of the victor as a higher synthesis. Critical theory was the attempt to come into the inheritance of dialectics without spinning victor's fantasies. It is the legacy of those who have been violated gains experience (Sloterdijk 2001: 375).

Critical theory never doubted the truths generated by scientific enterprise but it realized very soon that it accounted for nothing on its own and the supposed unity which it was ordained to fulfill was simply polemics ingrained in the principles of positive dialectics. Critical theory finally dispelled with the cherished idea that truth alone is sufficient to integrate the life on a higher level; that it alone could take care of everything else.

In this sense, it enacted the age old drama repeated many times in history, an idea acting as a hammer striking down the idol placed at that time at the altar of history. Lyotard in his description of postmodern condition also makes similar comments about critical theory that it was the outcome of the legitimation crisis of grand narrative of science (Lyotard 1984). Critical theory tried to save the subject, the individual from this crisis of legitimation by producing a new charter of 
individual emancipation. Critical theory did not place any great expectation on some future ideal; it also did not recover any convivial values or kynical impulses but only had oppositional characteristics which later paved the way of cynicism and bad faith.

Critical theory sought the unity only in an individual's self through a heightened sensitivity, which would integrate the moral, aesthetic and the spiritual dimensions of life. It left the society as a whole out of its ambit and therefore it could be said that it reduced the domain of ideology to its bare minimum, the individual and its emancipation. The motto of critical theory could best be summarized by one of the quotes from the founder Adorno that 'when everything is bad, it is better to know the worst' (Adorno 1974).

This desire to know the worst has informed most of the scholarships that has happened in social sciences, especially in the genre of cultural studies, which speak for the people, the subaltern, with vocabularies of power, oppression and emancipation. The inability to take anything at face value or to acknowledge the appearances of any construction, be it cultural or political; to look for hidden and ulterior motives behind every articulation; to suspect power and domination lurking behind everything; the critical theory becomes, in the words of Bruno Latour, 'one of the most powerful iconoclastic gestures of our times' (Latour 1999). Unlike the dialectics of classical Marxism, which apart from debunking irrationality, had a positive vision of truth that had to be realized by the society and the individual in the future, the power of critical theory comes from its power of negativity ingrained its construction. The positive truth had to be abandoned, for right reasons though, for the truth of individual self whose truthfulness consisted in its denial of any eschatological purpose of life.

\section{CONCLUSION}

What has been attempted here is far from a detailed analysis of history; in fact it would be naïve to think that that could be done in few pages, covering almost a period of over two and a half millennia. At most, it could be called a superficial meandering in historical time to get a partial glimpse of something that has been a constantly recurring theme, albeit in different forms, in every epoch. We have found from this brief incursion in history is the appearance of Iconoclasm which forms the subtext, the undercurrent, the propelling fire which has kin- 
dled the compulsive-repetitive march of societies (mostly Western) in history. From Judeo-Christian injunctions about the world to the postmodern cynicism, iconoclasm forms the leitmotif of every historical adventure. We have to be careful, not to confuse this leitmotif with the logic of history.

We are not proposing any logical explanation of historical epochs, but rather an unwarranted modus operandi palpable in all the cosmological-ideological formulations dealing with the world. This modus operandi, the act of iconoclasm has been identified as 'original sin' in history. Just as theological-mythological 'original sin' of Adam resulted in the 'fall of man' in the world; the historical original sin committed by Abraham (breaking the idols of his people) forced this Western civilization into in to a repetitive mode of history. Every revolution and reformation was trying to accomplish what was initiated during the Axial Age, to create a world devoid of things and multiplicities inscribed in the objects. From the work of Redactor during the Babylonian captivity to the cynicism of the Postmodern world, the desire to shake of the mediators and to arrive at a hidden truth has remained persistent and along with it the utility of the iconoclastic gesture. From the Axial ages to modernity and finally to postmodernity, this mainstreaming of iconoclasm has resulted in a compulsive-repetitive order of Western history.

In the end, we can say rephrasing Marx that all history has been a history of struggle against forms. It is this struggle against forms, by eternally returning and negating the negators gives the world history a semblance of forward march.

\section{NOTE}

* See Eric Voegelin (1952) where the process of immanentization has been described as the gradual emptying of the world of its mediating links and mediators by different reformist religious sects.

\section{REFERENCES}

Adorno, Th. 1974. Minima Moralia. London: Verso Books.

Assmann, J. 2008. Of God and Gods: Egypt, Israel and the Rise of Monotheism. Madison: University of Wisconsin Press.

Baskin, K., and Bondarenko, D. M. 2014. The Axial Ages of World History: Lessons for the 21st Century. Litchfield Park, AZ: Emergent Publications.

Baskin, K., and Bondarenko, D. M. 2019. Is Modernity a Third Axial Age? NETSOL 4 (2): 1-23. DOI: 10.24819/netsol2019.05. 
Bauman, Z. 1997. Post-Modernity and its Discontents. Cambridge: Polity Press.

Bijker, W. (ed.) 1995. Of Bicycles, Bakelite's, and Bulbs: Towards a Theory of Socio-Technical Change. Cambridge: MIT Press.

Bondarenko, D. M. 2007. What is There in a Word?: Heterarchy, Homoarchy, and the Difference in Understanding 'Complexity' in the Social Sciences and Complexity Studies. In Richardson, K. A., and Cilliers, P. (eds.), Explorations in Complexity Thinking: Pre-Proceedings of the 3rd International Workshop on Complexity and Philosophy (pp. 35-47). Mansfield, MA: ISCE Publishing.

Campbell, J. 2004. The Hero with a Thousand Faces. Princeton: Princeton University Press.

Cioran, E. M. 1975. A Short History of Decay. Oxford: Basil Blackwell.

Daston, L. (ed.) 1998. Biographies of Scientific Objects. Chicago: University of Chicago Press.

Deleuze, G. 1983. Nietzsche and Philosophy. New York: Columbia University Press.

Deleuze, G. 2005. A Thousand Plateaus: Capitalism and Schizophrenia. Minneapolis: University of Minnesota Press.

De Ridder-Symoens, H. 1992. A History of the University in Europe. Vol. I. Universities in the Middle Ages. Cambridge: The Cambridge University Press.

Diamond, J. 1997. Guns, Germs and Steel: The Fate of Human Societies. New York: W.W Norton.

Dostoyevsky, F. 1967. Crime and Punishment. New York: Airmont publishing.

Dostoyevsky, F. 1970. The Possessed. London: Heinemann.

Dostoyevsky, F. 2008. The Brothers Karamazov. London: Vintage Books.

Eliade, M. 1975. Myths, Dreams, and Mysteries: The Encounter between Contemporary Faiths and Archaic Realities. New York: Harper and Row.

Giddens, A. 1971. Capitalism and Modern Social Theory: An Analysis of Writing of Marx, Durkheim and Max Weber. Cambridge: Cambridge University Press.

Gillespie, M. A. 2009. The Theological Origins of Modernity. Chicago, IL: University of Chicago Press.

Hay, St. N. (ed.). 1963. Dialogue between a Theist and an Idolater. Calcutta: K.L. Mukhopadhyay.

Heidegger, M. 1975. Poetry, Language, Thought. Harper and Row: New York. James, W. 1978a. Pragmatism. Massachusetts: Harvard University Press.

James, W. 1978b. The Meaning of Truth. Massachusetts: Harvard University Press. 
156 Social Evolution \& History / September 2021

Jaspers, K. 1953. The Origins and Goal of History. New Haven, CN: Yale University Press.

Latour, B. 1999. Pandora's Hope: Essays on the Reality of Science Studies. Cambridge: Harvard University Press.

Latour, B. 2005. Reassembling the Social. Oxford: Oxford University Press.

Latour, B. 2010. On the Modern cult of the Factish Gods. London: Duke University Press

Latour, B. 2013. An Inquiry into the Mode of Existence: An Anthropology of the Moderns. Cambridge: Harvard University Press.

Latour, B. 2014. On Some Effects of Capitalism. Copenhagen: Lecture given at Royal academy.

Lyotard, J. F. 1984. The Postmodern Condition. Minneapolis: University of Minnesota.

Naipaul, V. S. 1981. Among the Believers: An Islamic Journey. London: Andre Deutsch.

Nietzsche, F. 1974a. Thus Spoke Zarathustra. London: Penguin Books.

Nietzsche, F. 1974b. The Gay Science. New York: Vintage Books.

Ridley, M. 2015. Evolution of Everything. London: 4th estate.

Serres, M. 1995a. Angels: A Modern Myth (F. Cowper, Trans.). Paris: Flammarion.

Serres, M. 1995b. Natural Contract (E. MacArthur \& W. Paulson, Trans.). Michigan: University of Michigan Press.

Serres, M. 2015. Statues (R. Burks, Trans.). New York: Bloomsbury Academic.

Shapin, S., and Schaffer, S. 1985. Leviathan and the Air-Pump: Hobbes, Boyle and the Experimental Life. Princeton: Princeton University Press.

Simondon, G. 1958. On the Mode of Existence of Technical Objects. Montaigne editions.

Sloterdijk, P. 2001. Critique of Cynical Reason (M. Eldred, Trans.). Minneapolis: University of Minnesota Press.

Sloterdijk, P. 2013. In the World Interior of Capital (W. Hoban, Trans.). Cambridge: Polity Press.

Stengers, I. 1984. Order Out of Chaos. New York: Bantam Books.

Voegelin, E. 1952. The New Science of Politics. Chicago: Chicago University Press.

Weber, M. 2003. The Protestant Ethics and the Spirit of Capitalism. New York: Dover publications. 